\title{
Employing ANDI Learning Model in Culinary Arts Course: How Does It Contribute to Emulation Ability and Students' Creativity?
}

\author{
Andi Hudiah \\ Engineering Faculty \\ Universitas Negeri Makassar \\ Makassar, Indonesia \\ ahudiah@unm.ac.id
}

\author{
Marji, Eddi Sutadji, Titi Mutiara Kiranawati \\ Engineering Faculty \\ Universitas Negeri Malang \\ Malang, Indonesia
}

\begin{abstract}
This study aims to investigate the contribution of ANDI learning model to emulation ability and its impact to students' creativity in culinary arts course. It involved 131 students majoring in culinary taken randomly from four state and private universities in different cities in Indonesia. The data were analyzed through Structural Equation Modelling (SEM) PLS. The result of the study showed that: (1) ANDI learning model contributed $32.6 \%$ to emulation ability, (2) ANDI learning model contributed $19.3 \%$ to students' creativity, (3) emulation ability contributeds $20,4,3 \%$ to student's creativity, (4) simultaneously, ANDI learning model and emulation contributed $39.7 \%$ to creativity in culinary arts course. As the conclusion, ANDI learning model contributed to emulation and eventually affected the student's creativity in culinary arts course.
\end{abstract}

Keywords - ANDI learning model, emulation, creativity, culinary arts

\section{INTRODUCTION}

The educational process evolves along with the technological development. Higher education institutions as a place to acquire knowledge virtually and not traditionally. Changes aim at using the latest communications and information technology, triggered the improvement of the quality of the competence of professional creativity as human capital. This is determined by the knowledge and ability to obtain such information from various sources [28]. The effect of product adjustment on satisfaction and continuity can be moderated by three activities a person can undertake during a new product development process: education, product knowledge development, and developing new products. The process of creativity allows the emergence of everything with new ideas, recognizing patterns and creating relationships. Having mastered the fundamental elements of a problem, it can be redefined or explored with a new technique [26].

Sokol et.al investigates the frequency of internet use in the learning process at selected higher education institutions to determine the effect of on-line learning on the competence of professional creativity as human capital. The results showed that the ability to use the internet in a higher learning process is parallel with the level of professional creativity competence. The competence of professional creativity is an element of intellectual capital and as a major factor of micro and macro scale development. Using information technology in the learning process at university has three areas on: (1) how to obtain information needed in educational process both for educator and student and its assessment in relation with usage (e-information); (2) communication forms (econtact), and (3) choice of traditional learning methods or methods that incorporate e-education and communication technologies. These areas facilitate independent and permanent learning, leading to reduced teaching costs and improving mass education.

In addition, a person who needs creativity should be open to ambiguity [25]. Creative individuals are able to bear ambiguity and risk, persist in overcoming obstacles, and seek new experiences because in this disagreement allows one to create creative solutions [26]. Furthermore, one must also flexible and treat new situations out of curiosity, interesting and exciting, and giving harmless and inspiring creative responses [25]. The much-needed further virtue is the consciousness that should be cater since too careful people can take action that will ultimately hinder creativity. Persistence, on the other hand, not only allows workers to accomplish tasks but also causes them to set high requirements. It is closely related to individuals' emulation ability. Character type conditioning is very important for a job of its own because it is this feature that allows to evaluate the actions that are truly effective and taken beforehand to create creative ideas, creative processes, creative recipes and creative products, when accumulated [25].

Individuals who have emulation ability are those who possess general ability above the average. They master their own field. Anyone who has an interest in a particular field will surely enjoy and implement in his life, as his interest in processing food and/or drink means either being able to narrate a food and/or drink, descriptively or sketched. Students interested in preparing food have pleasure in creating and processing their daily diet with that habit create ones with a desire to develop their creativity.

Yamamoto and Lambert, found that the appearance of industrial products gives effect, which in some situations exceeds the effect of product performance or certain price attributes. They suggest that the attention paid to the aesthetics of the product may give results in terms of sales performance. Furthermore, the impact of product appearance affects people in various organizational functions on various technical orientations. Management implications include the need for market-driven and customer-focused new product 
processes, greater emphasis on planning and launch implementation, product design roles, and project priority factors [27].

\section{METHOD}

This research used a quantitative approach, which described quantitatively, the tendencies, attitudes, or opinions of a population by examining the population sample [4]. Based on the formulation of problems and hypotheses that have been stated was to reveal whether ANDI learning model contributes to the ability of emulation and has impact on the creativity of culinary arts course. Exogenous variable $(\mathrm{X})$ is ANDI learning model, which will investigate whether there is contribution to endogenous variable (Y1) that is emulation ability, and how its impact to creativity in culinary arts course (Z1). This design used Structural Equation Modelling (SEM). It was used to analyze relationship pattern among variables with the aim to know the direct influence and indirect effect of exogenous variable on endogenous variables [20].

The population of this research was all students of Culinary Study Program of Home Economic Department, which offers culinary arts course in odd semester in state and private universities joined in Association of Indonesian Technical Education (APTEKINDO). The selected population of this study was from four universities: Universitas Negeri Makassar, Universitas Negeri Semarang, Universitas Negeri Medan, and Universitas Wira Buana Surabaya. The population was determined based on the availability of culinary arts course at the time of this study began.

In selecting the sample of the research, probability sampling was employed. This sampling technique provides equal opportunity for each member of the population to be selected as a sample member [19]. The selected sample was obtained using the formula from Slovin [20] and selected randomly from the odd and even number [29]. Based on the formula, the samples selected form each university are shown in Table I.

TABLE I. POPULATION AND SAMPLE

\begin{tabular}{|l|l|c|c|}
\hline No & \multicolumn{1}{|c|}{ University } & $\begin{array}{c}\text { Population } \\
\text { (students) }\end{array}$ & $\begin{array}{c}\text { Sample } \\
\text { (students) }\end{array}$ \\
\hline 1 & $\begin{array}{l}\text { UNM } \\
\text { (Universitas Negeri Makassar) }\end{array}$ & 55 & 36 \\
\hline 2 & $\begin{array}{l}\text { UNNES } \\
\text { (Universitas Negeri Semarang) }\end{array}$ & 50 & 33 \\
\hline 3 & $\begin{array}{l}\text { UNIMED } \\
\text { (Universitas Negeri Medan) }\end{array}$ & 40 & 22 \\
\hline 4 & $\begin{array}{l}\text { UNIPA } \\
\text { (Universitas Wira Buana Surabaya) }\end{array}$ & 60 & 40 \\
\hline \multicolumn{2}{|l|}{ Total } & $\mathbf{1 9 5}$ & $\mathbf{1 3 1}$ \\
\hline
\end{tabular}

In collecting the data, the researcher developed a set of questionnaire by following several steps: (1) identify the variables, (2) describe the variables to become indicators, (3) arrange sub-indicators of each indicator, (4) formulate each sub-indicators into instrument items, (5) equip instruments with filling instructions and introduction. The questionnaires are initially tested the validity and reliability.

The instrument used in in this study was a set of closed questionnaire with 4-points Likert scale. The questionnaire collected the data on (1) students' opinion on learning model of culinary arts (ANDI learning model) which consists of 36 items, (2) students' emulation ability which consists of 24 items, (3) students' creative thinking which consists of 18 items, and (4) students' creativity in culinary arts which consists of 33 items.

\section{RESULT AND DiscUSSION}

The analysis of the data collected encompasses structural equation model using Partial Least Square Analysis (PLS). It tested the contribution of ANDI learning model (X), emulation ability (Y1), creative thinking ability (Y2), creativity (Z1), and innovation (Z2). The development of the structural equation model can be illustrated in the Figure 1.

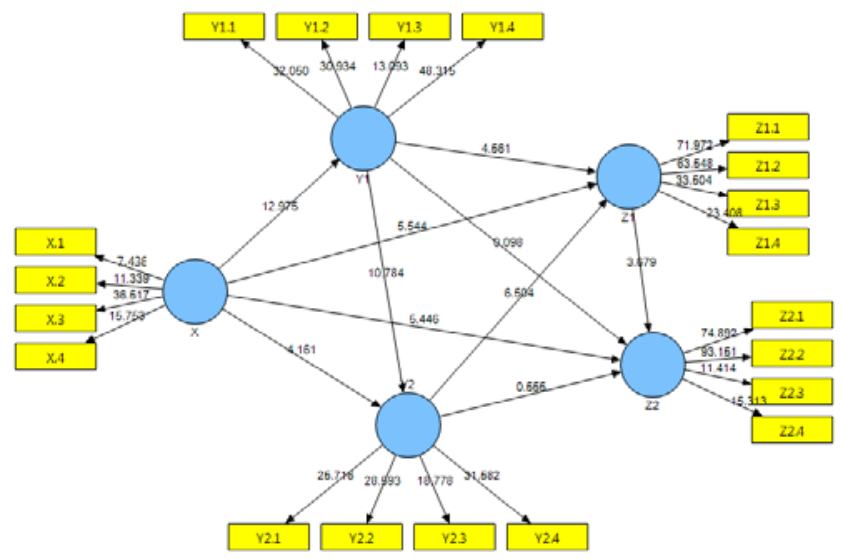

Fig. 1. Structural Equation Model of ANDI Learning Model (X), Emulation Ability (Y1), Creative Thinking Ability (Y2), Creativity (Z1), and Innovation (Z2)

1) Effect of ANDI Learning Model (X) and Creative Thinking Ability (Y2) on Emulation Capability (Y1)

The equation formed between the influence of ANDI learning model $(\mathrm{X})$ to emulation ability $(\mathrm{Y} 1)$ is:

$$
\mathrm{Y} 1=0.571 \mathrm{X}+\mathrm{u} 1
$$

From the equation, it shows that ANDI learning model (X) has a dominant influence on emulation capability (Y1).

2) Influence of ANDI Learning Model (X) and Emulation Capacity (Y1) to Creative Thinking Ability (Y2)

The equations formed among the influence of ANDI learning model $(\mathrm{X})$ to emulation ability (Y1) on creative thinking ability (Y2) is:

$$
\mathrm{Y} 2=0.259 \mathrm{X}+0.579 \mathrm{Y} 1+\mathrm{u} 2
$$

From the equation, it shows that emulation ability (Y1) has a dominant influence on creative thinking ability (Y2).

3) Effect of ANDI Learning Model (X), Emulation Capability (Y1), Creative Thinking Ability to Creativity Power (Z1)

The equation formed among the influence of ANDI learning model $(\mathrm{X})$, emulation ability (Y1), and creative thinking ability to creativity $(\mathrm{Z} 1)$ is:

$$
\mathrm{Z} 1=0.261 \mathrm{X}+0.275 \mathrm{Y} 1+0.429 \mathrm{Y} 2+\mathrm{u} 3
$$

From the equation, it shows that the ability to thinking creatively (Y2) has a dominant influence on creativity (Z1). 
4) Effect of ANDI Learning Model (X), Emulation Capability (Y1), Creative Thinking Ability, Creativity Power (Z1) on Innovation Power (Z2)

The testing of influence among ANDI learning model (X) to creativity power (Z1) through emulation capability (Y1) shows that t-statistic $(34,164)>$ t-table $(1,960)$ which means that there is significant influence between ANDI learning model (X) on creativity power (Z1) through emulation capability (Y1) with a significance level of 5 percent. Path coefficient $(0,157)$ with positive sign indicates positive influence, which means that the better ANDI learning model (X) the better creativity (Z1) through emulation ability (Y1).

5) Contribution of ANDI Learning Model to Emulation Ability

Testing of contribution of ANDI learning model and emulation ability got $t$-statistic value $(12,975)$ greater than $t$ table $(1,960)$ which means that it is a significant contribution between ANDI learning model to emulation ability with 5\% significance level. Based on the result of research, the contribution of ANDI learning model to the variable of emulation ability is $32.6 \%$, compared to its contribution to creativity on culinary arts course.

This research is closely related to the implementation of constructivist learning. Essentially, ANDI learning model is an approach in learning based on experience, which subsequently reorganized and constructed. ANDI learning model stands on the theory of cognitive constructivism by Piaget. The theory of cognitive constructivism studies states that knowledge is built into the minds of children [17]. Students have the opportunity to build their own knowledge through the activeness of self in the learning process. In addition, ANDI learning model is also based on social constructivism theory by Vygotsky, that is students gain their knowledge through social interaction in learning [1]. Students were given the opportunity to analyze, design and conduct experiments, supported by interaction with the team. The learning process should provide many stimuli to the students to be willing to interact with the environment actively, searching and finding various things from the environment in an effort to develop creativity and innovation [9,10,12]. Similarly, [33] found that the high discipline elevated the learning motivation will eventually the enhanced learning results.

Based on constructivist theory, ANDI learning model strongly supports the improvement of emulation ability. Emulation ability defines as the ability to synergize the elements of technology [14] which become the indicators of emulation ability, i.e., technoware, humanware, infoware, and orgaware. The analysis process aims to stimulate the emergence of the source of ideas and inspiration. This process cannot be separated from the synergy between the emulation ability, namely humanware that plays an active role in the involvement of infoware elements derived from the knowledge and experience it possesses combined with new information obtained from various sources of information [23,24,31]. Either from the internet, learning modules of culinary, or magazines. The obtained information then developed in the teamwork with an organized group discussion on the culinary arts course. This process spawned creative and innovative ideas to develop each individual in a group.
The result of a research conducted by [2] reveals that the group of students who learn with the learning model based on constructivist approach are more creative than the group of students taught with conventional model. Investigation on emulation by [6] found that the preschoolers are in the conditions of failed attempts. In emulation learning conditions, children under age of two do not see adults' manipulation and their responses are based on determining choices. Generally, they mimic the control that they observe under adult manipulation conditions. However, children over the age of three produce action in failed conditions [5]. These findings show that, learning emulation at first just mimics the seen actions, in the sense of being limited to imitative actions. Along with the knowledge and experience possessed and the newly acquired knowledge, simultaneously triggered the increase of learning the emulation. The demonstration on the object involves a number of social cognitive processes. Experimental design is needed to determine the role that a person is playing with the intent of emulation and imitation.

6) Contribution of ANDI Learning Model to Creativity in Culinary Arts Course

The results show that ANDI learning model contributes significantly to the students' creativity joining culinary arts course. The investigation on the contribution of ANDI learning model to creativity means that there is a significant contribution between ANDI learning model and creativity. Based on the results of the study, ANDI learning model contributes directly to creativity. This is because of the creativity process that has been planned prior in the process. In analysis step, students (a) select and search the main ingredients, supplementary ingredients and garnishes that will be used in producing culinary arts, (b) design processing preparation equipment, (c) design food processing equipment, (d) design the serving equipment, and (e) design processing methods following SCAMPER method (substitute, combine, adapt, magnify, put order to use, eliminate, rearrange). In narration step, students pour their creative ideas in the form of sketches or drawings of products to be developed, description of product ideas, reference recipe and the source of the ideas.

Narration is a type of writing that contains the plot, characterization, setting, which usually aims to convey the message to the readers. The purposes of the narrative in general are (1) giving information in the form of experience that presented aesthetically to the readers, (2) giving detail information of an event supported with narrative elements, (3) conveying experience for entertainment, (4) telling the truth about an event that has happened for a particular interest [16].

In the same vein, [18] argue that an effective narration can be supported with the addition of illustration, sketch, or image. Illustration is the result of visualization of a writing with drawing, painting, photography, or other arts techniques. Illustration emphasizes the relationship of the subject with the text in question. In objectify creative ideas, it is necessary to create a design that according to Kiswandono called as the process of creativity. It is pouring the source of ideas through a clear picture of the basic materials, and prints that will be used in the creation of his work. The creation of intuitive and methodical artwork is essentially a scientific work [21]. Both have passed the methodological stages of procedure from the determination of subject and object of creation, theoretical or empirical basis to include methods of 
creation coupled with techniques and ways to make it happen. Intuitive and methodical is the concept that arises when in the creative process there are two typical tendencies that work in contrast. Intuitive is more spontaneous while the methodical creative process is procedural and planned. Both are two types of creative process methods that are at the hardware level. A tool component that guides operations creation activities operationally. On the other hand, both intuitive and methodical methods are guided by a higher level of abstract tool or methodology, i.e. paradigms, approaches, and theories. Components of the tool as a software because it drives tools that are more operational hardware, i.e., methods, techniques, and how to work.

ANDI learning model through emulation contributes positively to the creativity of culinary arts. This can be due to the process of applying all the necessary skills in food processing, requiring a basic idea for designing what food, ingredients, techniques to use, models or shapes, and mold to use. Every person who will design food has the ability to source different ideas. Creating food / cuisine in addition must have the skills to process, also the source of ideas needed to design and create a creation. The source of ideas can give birth to creativity. High creativity in creating recipes can actually be derived from things that seem easy, namely the introduction of ingredients and cooking activities. Sometimes a small, unthinkable problem arises when selecting foodstuffs and processing them in the kitchen (Kiswandono, 2004: 10).

\section{7) Contribution of Emulation Ability to Creativity in Culinary Arts Course \\ The results show that the ANDI learning model} contributes positively and significantly to creativity in culinary arts course. It means that the better the students' emulation ability, the higher the creativity in creating the culinary arts. Creativity exists because of the influence of the environment. A person is required to be a creative person to develop the ability and to create something new. Creative people seen from the nature and behavior and the works that have been created [11]. Culinary arts course is the result of one's creative process because one of the abilities that must be possessed by students is the ability to be creative. The better the synergy between the components of technology in the creative process, in this case the process of designing the product as well as narrating or describing the product, the better the process of creativity of processing food into creative products. This process affects the selection of materials, the selection of preparation tools and processing equipment and presentation tools. In addition, the creative process also affects processing techniques, prescription trials, organoleptic tests and panel test. The creative process also affects the use of garnish. Wallas [22] describes four stages of the creative process, i.e., (1) preparation, (2) incubation, (3) illumination and (4) verification.

In line with the results of previous research, there are $86.25 \%$ students are categorized as very good in development step especially in doing experiments to produce creative recipes. This is because the initial knowledge and experience of students are already good and sufficient [8]. Initial knowledge of the students before attending the masterpiece of culinary work is trained in processing and serving food. Practical subjects in the previous semester strongly support the implementation of cake works especially cake master food processing courses.
Creativity is formed by four indicators namely person, process, press and product. Creativity is created through the ability of human thinking, but the term creativity has become one of the most complex issues to define. This is because some terms are defined variably from any term that has similarities, overlaps, and may be identical, for example; Imagination, intelligence, innovation, inspiration, creativity, thinking power, novelty, originality, ability, talent, unique (Plucker \& Makel 2010 in [26]). However, it may also find such terms as ability, reaction, capacity, process, person, product, uniqueness, novelty, in most definitions of creativity.

Creativity is the ability to increase something new for the size of the self. This means that this idea may not be novel when viewed from the side of the quantity of those who have used it, but the ability to apply to the self is qualitatively different from that done by others [30].

8) Contribution of ANDI Learning Model through Emulation Ability to Creativity in Culinary Arts Course

Creativity is an important part of culinary arts. Creativity requires the ability of emulation, someone who hone his emotional ability and develop it with the help of ANDI learning model is certainly the creativity in creating culinary products increases. The ability of emulation and creativity is closely related because creativity is one of the characteristics of emulation capabilities [14],[6]. Having a creative ability in creating culinary products, means having the power of creativity and the ability to create a culinary product to grow within a person. The results of the study [15] revealed that there is a correlation between the level of creativity and attraction of a person in the move. It takes the application of psychoeducation that aims to remove barriers to individual creativity.

\section{CONCLUSION}

The ability to create culinary products such as appetizers, main course, dessert, food industry, beverage, are the ability to analyze, design, compose, process and present products created. Supported by creative abilities, students will have more ideas gained from the process of developing all their talents. Creativity is needed in the process of designing culinary arts. In this case, it is the talent of analyzing, designing, composing, processing and presenting the culinary products. Creativity is not only to produce culinary products, but also plays a role in determining ideas and sources of ideas that support product creation. Therefore, it can be ascertained that creative ability is closely related to the process of creating a culinary product. Creativity is one of the most significant factors in the development of human resources because creativity is directly related to knowledge.

The ability to create culinary arts is one's ability to come up with the source of creative ideas, pouring them into narrative forms describing the basic ingredients and other additional ingredients, creating new products with high nutritional value and in suitable to product designation (teens, elderly, or all ages). Creating new products requires special skills, such as emulation skills and creativity. Someone who has the ability to emulate and creativity must have a desire to develop the ability to a higher level that is creating creative and innovative products. 


\section{REFERENCES}

[1] Archee, R. (2015). AEmulatio, imitatio and mimesis in tertiary education. Procedia - Social and Behavioral Sciences (174): 2418 2424.

[2] Arnyana, I. B. (2006). Pengaruh penerapan strategi pembelajaran inovatif pada pelajaran biologi terhadap kemampuan berpikir kreatif siswa SMA. Jurnal Pendidikan dan Pengajaran IKIP Negeri Singaraja, 3 (6).

[3] Branch, R. M. (2009). Instructional design: the ADDIE approach. New York: Springer.

[4] Creswell, J, W. (2013). Research design: qualitative, quantitative, and mixed methods approaches. (4th ed). Thousand Oaks, CA: Sage.

[5] D'Entremont, Barbara. A., \& Yazbek. (2007). Imitation of intentional and accidental action by children with autism. Department of psychology, University of New Brunswick. Springer Science.

[6] Huang, C.T., Heyes, C., \& Charman, T. (2006). Preschoolers' behavioral reenactment of "failed attempts": the roles of intentionreading, emulation and mimicry. Elsevier - Cognitive Development, 21(1): 36-45.

[7] Hudiah, A. (2017). Developing constructivist e-learning for exhibition class of home economics students in State University of Makassar. IJEAR, 7(1): 9-11)

[8] Hudiah, A. (2015). Pembelajaran konstruktivistik berbasis e learning pada mata kuliah cipta karya boga jurusan PKK FT UNM. Prosiding Seminar Nasional LP2M. UM Malang.

[9] Jensen, E. (2011). Pembelajaran Berbasis Otak. Paradigma Pengajaran Baru. Edisi Kedua. Jakarta: Indeks.

[10] Kabukcu, E. (2015). Creativity process in innovation oriented entrepreneurship: The case of Vakko. Procedia - Social and Behavioral Sciences, 195: 1321-1329.

[11] Kudrowitz, B., Oxborough, A., Choi, J., \& Stover, E. (2014). The chef as designer: Classifying the techniques that chefs use in creating innovative dishes. Seminar Design Research Society Conference. Umea: Swedia.

[12] Marzano, R. J. (2013). Seni dan Ilmu Pengajaran. Jakarta: Indeks.

[13] Mukhadis, A. (2012). Kemampuan emulasi sebagai orientasi pendidikan entrepreneurship di abad pengetahuan. Proceeding Seminar Nasional Cakrawala Pembelajaran Berkualitas di Indonesia.

[14] Mukhadis, A. (2013). Sosok Manusia Indonesia Unggul dan Berkarakter dalam Bidang Teknologi sebagai Tuntutan Hidup. Jurnal Pendidikan Karakter, 3 (2).

[15] Mynbayeva, A., Vishnevskay, A., \& Sadvakassova, Z. (2016). Experiment study of developing creativity of university students. Procedia - Social and Behavioral Sciences, 217: 407-413.

[16] Nurbaya. (2016). Efektivitas penggunaan media komik dalam pembelajaran menulis karangan narasi peserta didik kelas V MI Juluati Palulung kecamatan Tombolo Pao kabupaten Gowa. Undergraduate Thesis. UIN Alauddin Makassar

[17] Petchtone, P. (2014). The development of instructional model integrated with thinking skills and knowledge constructivism for undergraduate students. Procedia - Social and Behavioral Sciences, 116: $4283-4286$.
[18] Ren, W. W., Waluyanto, H. D., \& Zacky, A. A. (2016). Perancangan buku cerita bergambar" peristiwa sejarah gerbong maut, bondowoso" untuk anak usia 13-18 tahun. Jurnal DKV Adiwarna, 1(8), 9.

[19] Riduwan, (2015). Skala Pengukuran Variabel-variabel Penelitian. Bandung: Alfabeta.

[20] Riduwan \& Kuncoro. (2013). Cara Menggunakan dan Memakai Path Analysis (Analisis Jalur). Bandung: Alfabeta.

[21] Runco, M.A., Selcuk Acar, S., \& Nur Cayirdag, N. (2017). A closer look at the creativity gap and why students are less creative at school than outside of school. Thinking Skills and Creativity, 24(-): 242-249.

[22] Sadler-Smith, E. (2015). Wallas' four-stage model of the creative process: more than meets the eye?. Creativity Research Journal, 27(4): 342-352.

[23] Shee, H.K., \& Pathak R.D. (2005). Managing people and technology for enhancing competitiveness, Journal of Transnational Management, 63-80.

[24] Smith, R., \& Sharif, N. (2007). Understanding and acquiring technology assets for global competition, Technovation, 27(-): 643649.

[25] Sokol, A., Figurska, I., \& Blaskova, M. (2015). Using the internet to enhance teaching process at universities for the development of creativity competencies. Procedia - Social and Behavioral Sciences, 186: $1282-1288$

[26] Sternberg, R, J. (2012). The assessment of creativity: An investmentbased approach. Creativity Research Journal, 24(1): 3-12.

[27] Stierand, M., Dorfler, V., \& MacBryde, J. (2014). Innovation of extraordinary chefs: Development process or systemic phenomenon?. Inggris: University of Strathclyde.

[28] Stump, R.L., Athaide, G.A., \& Joshi, A.W. (2002). Managing sellerbuyer new product development relationships for customized products: a contingency model based on transaction cost analysis and empirical test. Journal of Product Innovation Management, 19(6): 439-454.

[29] Sugiyono. (2015). Metode Penelitian \& Pengembangan. Research and (Development R \& D). Bandung: Alfabeta.

[30] Suwandeea, S., Krittanathipa, V., Ratanamaneichata, C., Rakkarna, S., \& Cha-uma, S. (2013). Creativity, innovation and development of novel products in cooperative sector in Thailand. Procedia - Social and Behavioral Sciences, 88 (-): $28-36$.

[31] Walujani. (2011). Pengaruh teknologi terhadap daya saing ikm keramik hias pada sentra industri keramik plered. Tesis Institut Teknologi Bandung.

[32] Yamamoto, M., \& Lambaert, D. R. (1994). The impact of product aesthetics on the valuation of industrial products. Journal of Product Innovation Management, 11(4): 309-324.

[33] Yussi, Syaad, \& Purnomo. (2016). The contribution of vocational students' learning discipline, motivation and learning results. International Journal of Environmental \& Science Education, 12(5): 965-970. 